\section{Effects of Sodium Thiocyanate on the Development of Amphibia}

IN previous work it has been shown that the notochord of embryos of Rana esculenta L., which from the late blastula stage onwards have been kept in solutions of $0.5-1$ per cent sodium thiocyanate for 12-48 hr., appear hyperdeveloped in comparison with the controls ${ }^{1}$. The same effect can be observed in embryos of the axolotl of Amblystoma tigrinum Green ( $=A$. mexicanum Cope) and likewise in lampreys (Petromyzon [= Lampetra $]$ planeri Bl.). A similar effect occurs under the influence of sodium iodide, vital dyes (pyocyanin, methylene-blue) and paranitrophenol ${ }^{2}$. Some details of the alterations in development produced by sodium thiocyanate are given below.

The hyperdevelopment of the notochord characteristic of the influence of sodium thiocyanate becomes evident through enlargement of the area of crosssection of the notochord. Often, especially when the experimental larvæ are shorter than the controls, the notochord folds up. In these larvæ the notochord. is longer than the body. From a comparative estimate of the volume of the notochord one finds, for example, in a larva of Rana esculenta (Fig. 2) originating from a blastula kept in 0.5 per cent solution of $\mathrm{NaSCN} .2 \mathrm{H}_{2} \mathrm{O}$ for $48 \mathrm{hr}$., a volume of $86 \times 10^{6} \mu^{3}$ as against $48.5 \times 10^{6} \mu^{3}$ in the control (Fig. 1). This increase in volume is due to an increase in the number of cells already present in the rudiment of the notochord. In fact, as soon as the notochord is well defined, we have counted 1,561 cell-nuclei in the notochord of an embryo kept for $24 \mathrm{hr}$. in 0.5 per. cent solution of sodium thiocyanate as against 1,090 in the control. When treated after neurulation, but before the tail-bud stage, one obtains larvæ with a notochord which is enlarged in the tail, but normal in the trunk.

Parallel to the increase in the dimensions of the notochord are phenomena of hyperevocation. In several embryos a large mass of cells is formed which occupies the roof of the encephalic vesicles from the posterior part of the middle-brain to the hind-brain. This mass in some cases reaches the spinal cord. The cells of this mass in part degenerate ; the rest form a ganglion lying in the median line in the roof of the fourth ventricle. The cross-section of the mylencephalon of these embryos is larger, and the lumen of the fourth ventricle may be obliterated by the growth of this ganglion.

All these alterations seem to be the reverse of those produced by the action of lithium chloride, which causes an inhibition of the development of the notochord and of the prechordal plate and thus a hypoevocation, namely, cyclopia ${ }^{3}$. Experiments were made in order to determine what kind of substances are capable of producing cyclopia in embryos of the frog and axolotl. These were found to be substances which precipitate proteins. The stronger they are in Hofmeister's series, the more readily do they produce cyclopia". Sodium thiocyanate and sodium iodide, which produce monsters with hyperdeveloped notochords and hyperevocation, inhibit protein precipitation. Sodium thiocyanate, which has the greater effect, is the more inhibitory according to Hofmeister's series. The vital dyes and paranitrophenol, which cause an increase in respiration, have the same action as the inhibitory substances. This shows itself in various phenomena of embryonic development. One can obtain 'animalization' of the

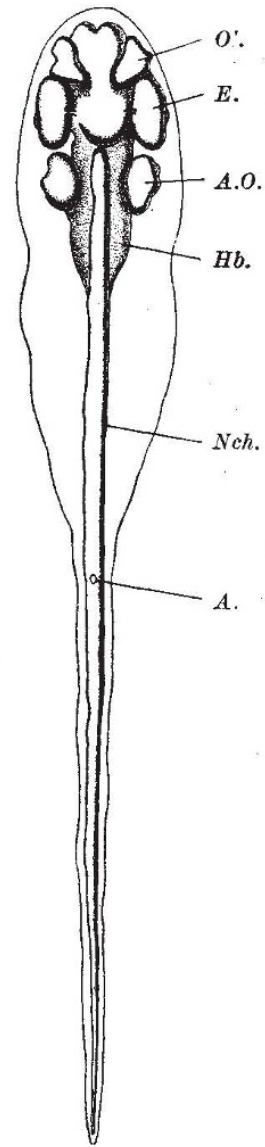

Fig. 1.

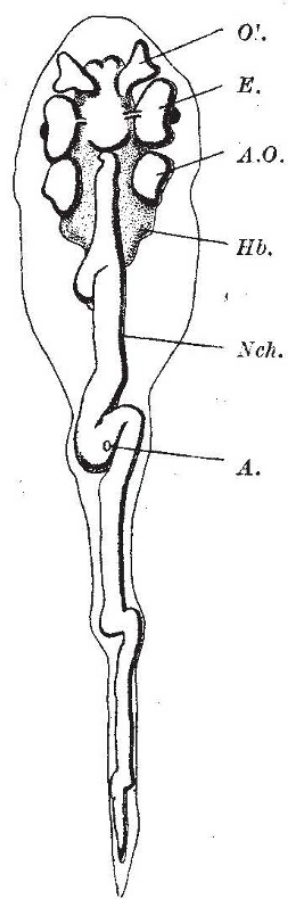

Fig. 2.
Figs. 1 and 2. REOONSTRUCTIONS OF THF NOTOCHORD $\triangle N D$ OF THE NERVOUS SYSTEM $\triangle$ S SEEN FROM THE VENTRAL SIDE: (1) OF THE NERVOUS SYSTEM AS SEEN FROM THE VENTRAL SIDE : (1) OF THE
CONTROL IAARVA; (2) OF A LARVA WHICH AS A LATE BLASTULA WAS KEPT FOR 48 HR. IN 0.5 PER OENT SOLUTION OF NaSCN. $2 H_{2} \mathrm{O}$; A., LEVEL OF THE ANUS; A.O., OTOCYST ; $E .$, EYE-CUP; H H., HIND
BRAIN ; Nch., NOTOCHORD ; Ol., OLPACTORY ORGAN. ( 17.$)$

embryos of echinoderms both with sodium thiocyanate and sodium iodide ${ }^{5}$ and also, though to a lesser extent, with the vital dyes or paranitrophenol ${ }^{\text {. }}$. Ventral explantations of young gastrulæ of Amphibia show neural evocation, whether cultured in Holtfreter's liquid containing sodium thiocyanate ${ }^{7}$ or vital $d y e^{8}$. In these experiments sodium thiocyanate is more active than methylene-blue?

The similarity of action of the vital dyes and sodium thiocyanate in these experiments is not yet clear.

Zoological Laboratory,

Silvio Ranzi.

Royal University, Milan.

At the Zoological Station, Naples.

Jan. 24.

${ }^{1}$ Raszl, S., and Tamini, E., Naturwiss., 27, 566 (1939),

a Citterio, P., Rend. R. Ist. Lombardo (Cl. Sci.), 75, 142 (1942). Bartolazzi, C., Rend. R. Ist. Lombardo (Cl. Sci.), 75, 474 (1942). Ranzi, S., Boll. Soc. Ital. Biol. Sper., 18, 314 (1943).

s Lehmann, F. E., Roux' Arch., 138, 106 (1938).

'Tamini, E., Roux' Arch., 142, 455 (1943).

${ }^{5}$ Lindahl, P. E., Acta Zool., 17, 179 (1936).

-Waterman, A. J., Biol. Bull., 75, 376 (1938). Tamini, E., Monit. Zool. Ital., 52, 81 (1941).

'Ranzi, S., and Tamini, E., Rend. R. Ist. Lombardo (Cl. Sci.), 78, $525(1940)$. 8 Beatty, R. A., de Jong, S., and Zielinski, M. A., J. Exp. Biol., 16,
150 (1939). 